\title{
PENGARUH PEMBERIAN YOGHURT KORO PEDANG (Canavalia ensiformis) TERHADAP KADAR KOLESTEROL LDL DAN HDL SERUM TIKUS SPRAGUE DAWLEY DISLIPIDEMIA
}

\author{
Nurul Alam Sayekti, Ninik Rustanti") \\ Program Studi Ilmu Gizi Fakultas Kedokteran Universitas Diponegoro \\ Jl.Dr.Sutomo No.18, Semarang, Telp (024) 8453708, Email : gizifk@ undip.ac.id
}

\begin{abstract}
Background: Cardiovascular diseases are the number one cause of death worldwide. Jack bean (Canavalia ensiformis) is underutilized legume that has the potential in lowering serum cholesterol level. Yoghurt processing reduce the antinutritional factor of jack bean and improve the activity of its cholesterol level lowering components. The objective of this study was to determine the effect of jack bean based yogurt on LDL and HDL cholesterol level in dyslipidemic Sprague Dawley rat.

Methods: This was true experimental study using pre-post test with randomized control group design. The subjects were male dislipidemic Sprague Dawley rat. The rats administered jack bean based yogurt by the dose of $2.1 \mathrm{ml}$ and $4.5 \mathrm{ml}$ for 21 days. LDL and HDL cholesterol level measured using enzymatic method.

Result: Administration of jack bean yogurt by $2.1 \mathrm{ml} /$ day and $4.5 \mathrm{ml} /$ day did increase LDL-c level insignificanly ( $p>0.05$ ) by $5.41 \%$ and $0.01 \%$ respectively. LDL-c level on control group increased by $8.55 \%$, the increase was higher than treatment group. HDL-c level also did increase insignificanly ( $p>0.05)$ on $2.1 \mathrm{ml} /$ day and $4.5 \mathrm{ml} / \mathrm{day}$ dose group by $29.95 \%$ and $32.67 \%$ respectively while HDL-c level on control group decreased by $2.26 \%$.

Conclusion: Jack bean yogurt administration increased HDL-c, but it couldn't decrease LDL-c level. On contracy, it increased LDL-c level though the increase was lower than control group.

Keyword: yogurt; jack bean; Canavalia ensiformis; HDL; LDL; dyslipidemia
\end{abstract}

\section{ABSTRAK}

Latar Belakang: Penyakit kardiovaskuler merupakan penyebab utama kematian di dunia. Koro pedang merupakan polong-polongan yang berpotensi menurunkan kadar kolesterol darah. Pengolahan yoghurt dapat meminimalisir zat antinutrisi koro pedang dan meningkatkan aktivitas penurun kolesterol koro pedang. Penelitian ini bertujuan mengetahui pengaruh yoghurt koro pedang terhadap kadar LDL dan HDL serum tikus Sprague Dawley dislipidemia.

Metode: Penelitian ini berjenis true experimental dengan pre-post test with randomized control group design. Subjek penelitian adalah tikus jantan Sprague Dawley dislipidemia yang diberi yoghurt koro pedang dosis $2.1 \mathrm{ml}$ dan 4.5 ml selama 21 hari. Kadar LDL dan HDL diukur dengan metode enzimatik.

Hasil: Pemberian yoghurt koro pedang $2.1 \mathrm{ml} / \mathrm{hari}$ dan $4.5 \mathrm{ml} / \mathrm{hari}$ meningkatkan kadar LDL secara tidak bermakna $(p>0.05)$ sebesar $5.41 \%$ dan 0.01\%. Peningkatar LDL pada kelompok kontrol lebih besar, yaitu sebesar $8.55 \%$. Kadar HDL mengalami peningkatan tidak bermakna ( $p>0.05)$ sebesar $29.95 \%$ pada dosis pemberian 2.1 ml/hari dan $32.67 \%$ pada dosis 4.5 ml/hari sementara kadar HDL kelompok kontrol mengalami penurunan sebesar $2.26 \%$.

Simpulan: Pemberian yoghurt koro pedang meningkatkan kadar HDL namun tidak mampu menurunkan kadar LDL. Yoghurt koro pedang bahkan meningkatkan kadar LDL tikus meskipun kenaikan kadar LDL kelompok perlakuan lebih rendah dibandingkan dengan kelompok kontrol.

Kata kunci: yoghurt; koro pedang; Canavalia ensiformis; LDL; HDL; dislipidemia

\section{PENDAHULUAN}

Penyakit kardiovaskuler merupakan penyebab utama kematian di dunia dan lebih dari $80 \%$ kematian tersebut terjadi di negara berkembang. Menurut Riset Kesehatan Dasar (Riskesdas) tahun 2007, prevalensi kejadian penyakit kardiovaskuler di Indonesia adalah sebesar $7,2 \% .^{1,2}$

Salah satu faktor risiko terjadinya penyakit kardiovaskuler adalah dislipidemia. Dislipidemia merupakan keadaan abnormalitas profil lipid seperti naiknya kadar kolesterol total, trigliserida, kolesterol Low Density Lipoprotein (LDL), dan turunnya kolesterol High Density Lipoprotein (HDL). Kolesterol LDL dan HDL memiliki pengaruh langsung terhadap pembentukan plak pada dinding arteri sehingga terjadi penyempitan arteri atau atherosklerosis. Dislipidemia merupakan faktor risiko yang dapat diubah, salah satunya dengan pengaturan diet yang tepat, salah satunya adalah dengan mengkonsumsi makanan yang mengandung zat penurun kolesterol seperti antioksidan, protein nabati, stanol, dan sterol. ${ }^{3,4}$ Salah satu bahan makanan yang memiliki potensi 
antihiperkolesterolemia adalah biji koro pedang (Canavalia ensiformis).

Penelitian terdahulu menunjukkan bahwa ekstrak biji koro pedang dapat menurunkan kadar kolesterol total tikus Wistar diabetes mellitus dari $2.98 \pm 0.05 \mathrm{mmol} / \mathrm{L}$ menjadi $1.80 \pm 0.03 \mathrm{mmol} / \mathrm{L}$ (penurunan sebesar 39.6\%) dan kadar trigliserida tikus dari $1.83 \pm 0.01$ menjadi $0.76 \pm 0.05 \mathrm{mmol} / \mathrm{L}$ (penurunan sebesar 58.5\%). Penurunan kolesterol dan trigliserida ini diduga disebabkan oleh keberadaan saponin dalam biji koro. Saponin dapat menurunkan kolesterol dengan cara mengikat kolesterol dalam lumen usus, menghambat penyerapan kolesterol tersebut, dan/atau berikatan dengan asam empedu sehingga meningkatkan ekskresi kolesterol melalui feses. Selain saponin, biji koro pedang juga mengandung serat, fenol, isoflavon, flavonoid, serta tannin yang berpotensi menurunkan kolesterol. ${ }^{5-8}$

Disamping kandungan gizi yang bermanfaat, biji koro pedang juga mengandung komponen antinutrisi yang tidak diharapkan keberadaannya untuk dikonsumsi. ${ }^{6}$ Pengolahan menjadi yoghurt merupakan salah satu alternatif untuk meminimalisir zat antinutrisi tersebut dan meningkatkan aktivitas komponen penurun kolesterol dalam koro pedang. ${ }^{9,10}$

Berdasarkan uraian di atas, maka perlu dilakukan penelitian mengenai pengaruh pemberian yoghurt koro pedang tersebut terhadap profil lipid, khususnya kadar HDL dan LDL yang berperan langsung dalam kejadian atherosklerosis, pada tikus Sprague Dawley dislipidemia.

\section{METODE Subyek}

Subyek yang digunakan pada penelitian ini adalah tikus jantan Sprague Dawley, berumur \pm 3 bulan dengan berat badan 190-260 gram yang diperoleh dari Laboratorium Penelitian dan Pengembangan Terpadu (LPPT) Universitas Gadjah Mada.

\section{Bahan}

Bahan yang digunakan meliputi yoghurt koro pedang yang dibuat dari susu koro pedang yang difermentasi dengan Lactobacillus bulgaricus dan Streptococcus thermophillus selama 7 jam, pakan tinggi kolesterol berupa suspensi otak sapi yang terbuat dari otak sapi kukus yang diblender bersama aquadest dengan perbandingan 1:1, pakan standar serta minum air ad libitum.

\section{Metode Penelitian}

Penelitian berjenis true experimental dengan pre-post test with randomized control group design. Variabel bebas adalah yoghurt koro pedang dan variabel terikat adalah kadar kolesterol LDL dan HDL tikus. Pemilihan subyek penelitian untuk pengelompokan dan perlakukan dengan simple random sampling. Sampel dibagi menjadi 3 kelompok sebagai berikut:

K : Kelompok kontrol, diberikan pakan standar + air minum ad libitum

P1 : Kelompok perlakuan 1, diberikan pakan standar + yoghurt koro pedang $2.1 \mathrm{ml}+$ air minum ad libitum

P2 : Kelompok perlakuan 2, diberikan pakan standar + yoghurt koro pedang $4.5 \mathrm{ml}+$ air minum ad libitum

Masing-masing kelompok perlakuan terdiri dari 7 ekor tikus sehingga jumlah keseluruhan sampel adalah 21 ekor tikus.

\section{Tahapan Penelitian}

Penelitian dilaksanakan dengan enam tahap yaitu aklimatisasi, pengambilan darah awal, pemberian pakan tinggi kolesterol, pengambilan darah kedua, pemberian yoghurt koro pedang, dan pengambilan darah akhir.

Tikus dipelihara dalam kandang individual di ruangan bersuhu $22-25^{\circ} \mathrm{C}$ dan siklus pencahayaan 12 jam serta diberi pakan standar sebanyak 20 gram dan air minum ad libitum setiap harinya.

Seluruh sampel diadaptasi dengan lingkungan baru selama 4 hari, kemudian sampel dipilih sacara acak untuk menentukan kelompok K, $\mathrm{P} 1$, dan $\mathrm{P} 2$, lalu diberikan pakan tinggi kolesterol berupa suspensi otak sapi sebanyak $2 \mathrm{ml} /$ tikus/hari selama 14 hari. Selanjutnya kelompok P1 dan P2 diberikan yoghurt koro pedang dengan dosis 2.1 $\mathrm{ml} /$ hari dan $4.5 \mathrm{ml} /$ hari selama 21 hari.

Pengambilan darah dari plexus retroorbitalis tikus Sprague Dawley yang kemudian darah disentrifuge untuk mendapatkan serumnya. Kadar kolesterol LDL dan HDL diukur dengan metode enzimatik dengan spektrofotometer.

\section{Analisis Data}

Data yang dikumpulkan berupa jumlah asupan pakan standar, pemantauan berat badan tikus setiap harinya, data kolesterol LDL dan HDL awal, hiperkolesterolemia, dan akhir. Data dianalisis normalitasnya dengan uji Shapiro-Wilk. Perbedaan kadar kolesterol LDL dan HDL serum sebelum dan sesudah perlakuan kelompok diuji dengan dependent-t test bila distribusi data normal. Apabila tidak berdistribusi normal dilakukan uji statistik non parametrik Wilcoxon. Perbedaan pengaruh dari kedua kelompok perlakuan dianalisis dengan uji ANOVA bila data tersebut 
berdistribusi normal. Apabila tidak berdistribusi

Kruskal Wallis.

normal maka dilakukan uji statistik non parametrik

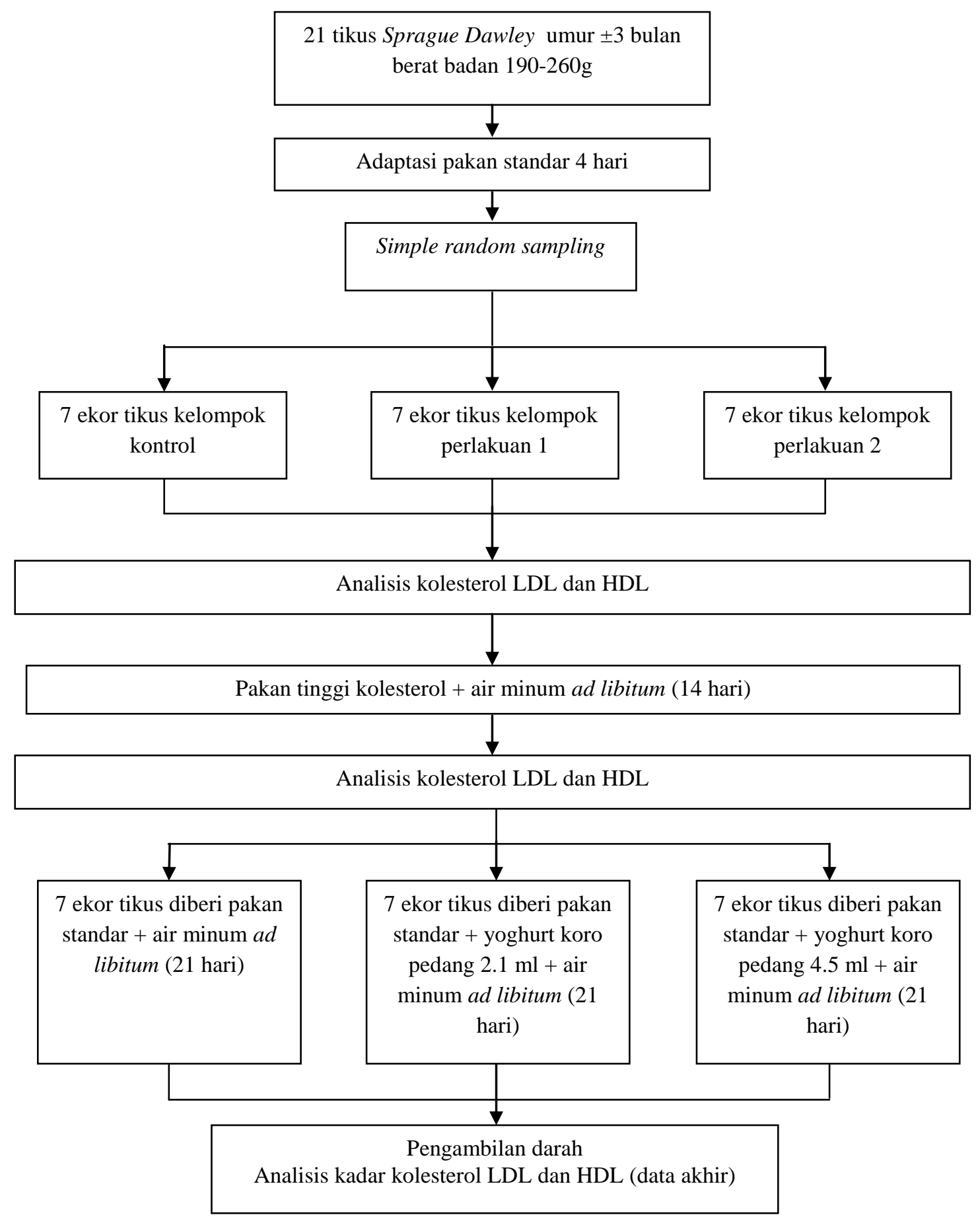

Gambar 1. Alur kerja penelitian

HASIL

Perkembangan berat badan dan asupan tikus

Penimbangan berat badan dan sisa pakan

tikus dilakukan setiap hari. Perkembangan berat badan dan asupan tikus dapat dilihat pada Gambar 2 dan 3. 


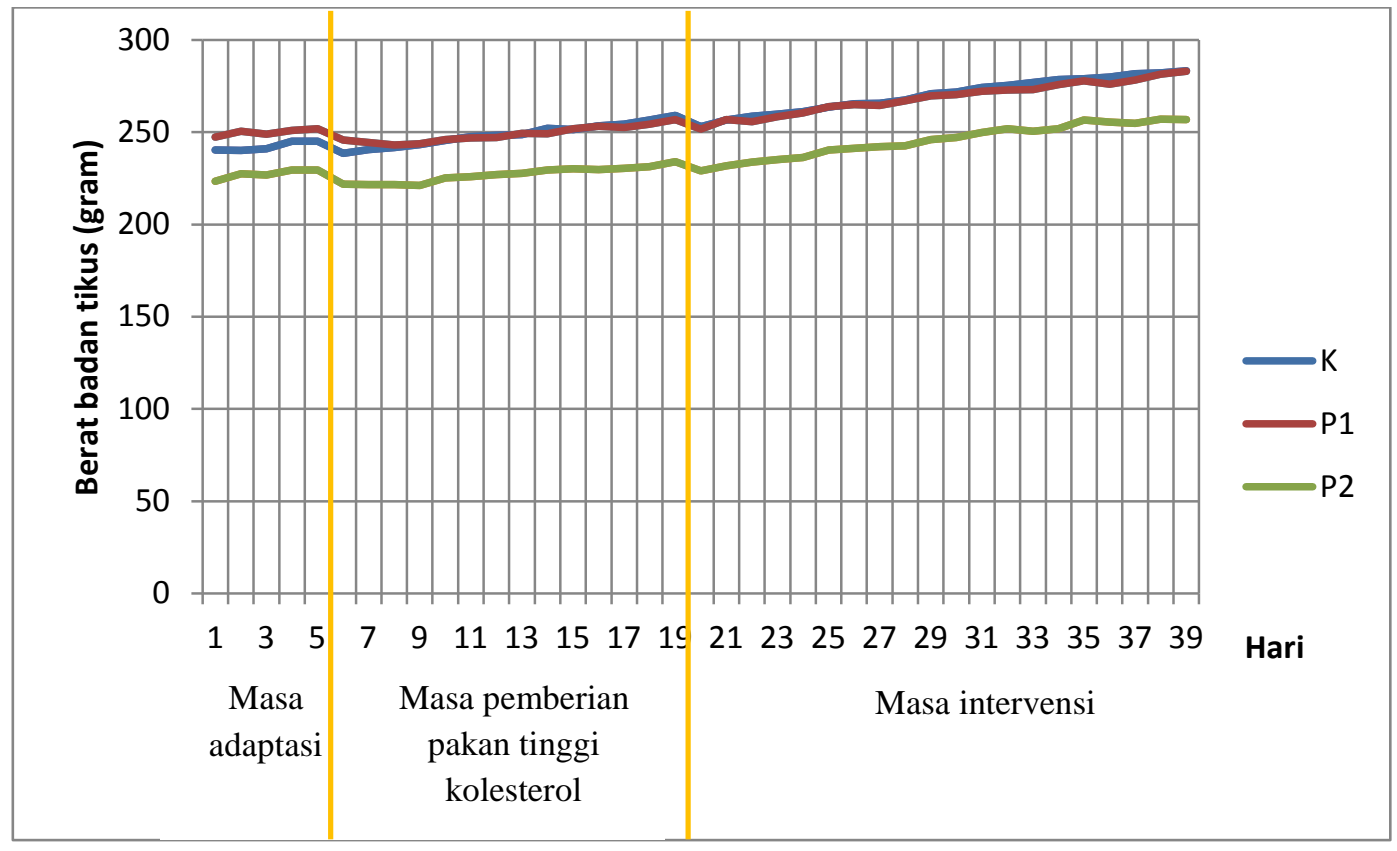

Gambar 2. Perkembangan rerata berat badan tikus

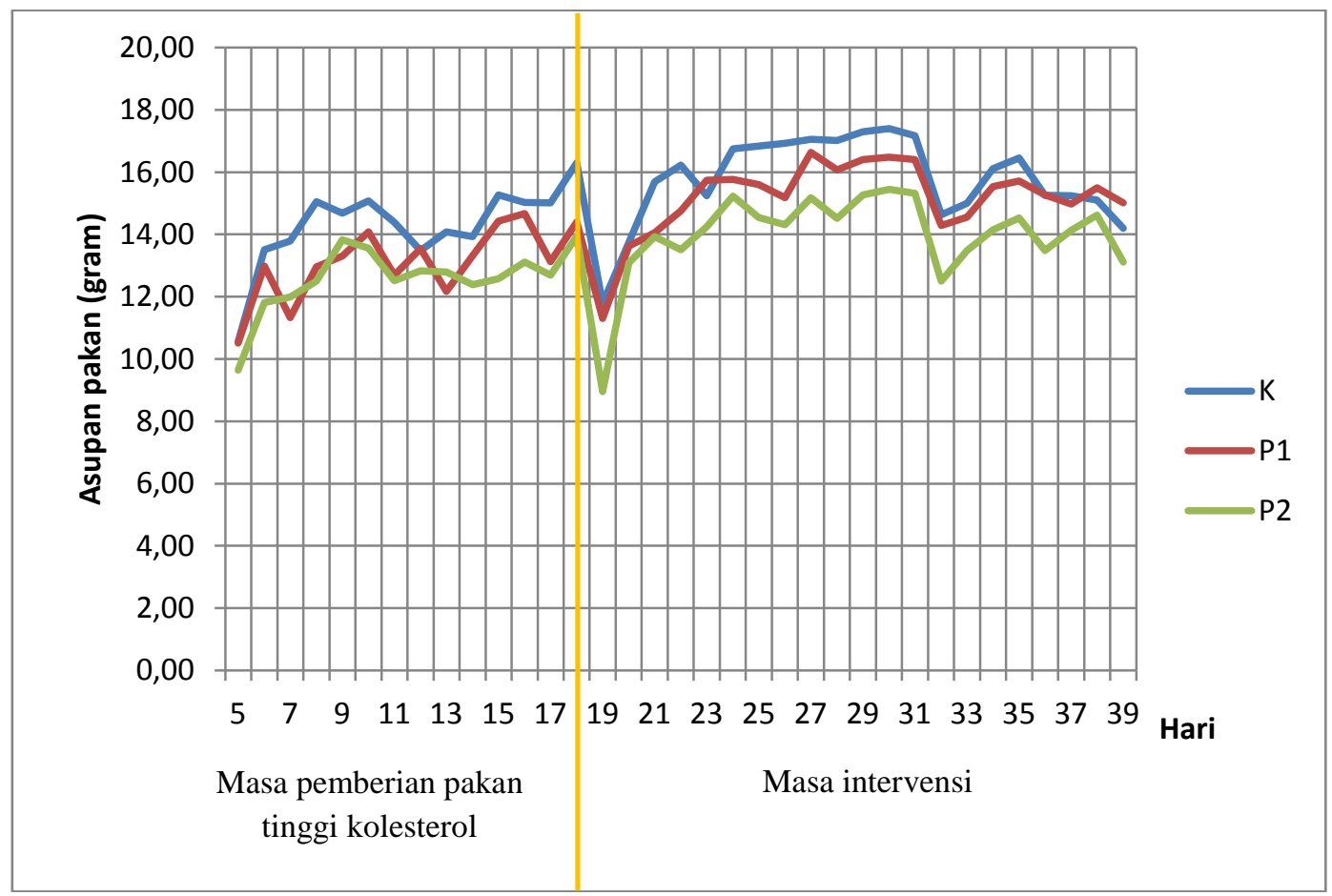

Gambar 3. Perkembangan rerata asupan pakan tikus

Gambar 2 menunjukkan berat badan tikus secara keseluruhan cenderung mengalami kenaikan. Rerata berat badan awal pada kelompok $\mathrm{P} 1$ lebih tinggi dibanding kelompok $\mathrm{K}$ dan $\mathrm{P} 2$, namun pada masa perlakuan, peningkatan berat badan kelompok $\mathrm{K}$ lebih pesat dibandingkan dengan kelompok P1 dan P2. Terjadi penurunan berat badan pada semua kelompok setelah pengambilan darah.

Asupan pakan pada semua kelompok cenderung tidak konsisten, namun dari Gambar 3 dapat dilihat adanya sedikit peningkatan jumlah asupan pada semua kelompok. Penurunan asupan secara drastis terjadi pada hari-18, yaitu setelah pengambilan darah ke dua. Penurunan jumlah 
asupan juga terjadi pada hari-32. Hal ini kemungkinan disebabkan oleh peningkatan suhu ruang hingga $28^{\circ} \mathrm{C}$.

Kadar kolesterol LDL dan HDL setelah pemberian pakan tinggi kolesterol
Rerata perubahan kadar kolesterol LDL dan HDL setelah tikus diberikan pakan tinggi kolesterol dapat dilihat pada Tabel 1.

Tabel 1. Kadar LDL dan HDL sebelum dan sesudah pakan tinggi kolesterol

\begin{tabular}{|c|c|c|c|c|}
\hline & \multicolumn{2}{|c|}{ Rerata (mg/dl) } & \multirow[b]{2}{*}{$\Delta(\%)$} & \multirow[b]{2}{*}{$p$} \\
\hline & $\begin{array}{c}\text { Sebelum pakan } \\
\text { kolesterol }\end{array}$ & $\begin{array}{c}\text { Sesudah pakan } \\
\text { kolesterol }\end{array}$ & & \\
\hline LDL & $25.66 \pm 4.993$ & $27.65 \pm 6.346$ & 7.75 & 0.072 \\
\hline HDL & $10.81 \pm 3.062$ & $11.65 \pm 2.708$ & 7.80 & 0.071 \\
\hline
\end{tabular}

Dari tabel di atas dapat dilihat bahwa baik kadar LDL maupun HDL mengalami kenaikan yang tidak bermakna $(p>0.05)$. Kenaikan LDL adalah sebesar $7.75 \%$, sementara HDL sebesar $7.8 \%$.

\section{Kadar kolesterol LDL dan HDL setelah pemberian yoghurt koro pedang}

Berdasarkan hasil penelitian, didapatkan rerata kadar kolesterol LDL dan HDL sebelum dan setelah diberikan perlakuan yang dapat dilihat pada Tabel 2 dan 3.

Tabel 2. Perbedaan rerata kadar kolesterol LDL sebelum dan setelah diberikan yoghurt koro pedang pada tiap kelompok perlakuan

\begin{tabular}{cccccc}
\hline \multirow{2}{*}{ Kelompok } & \multicolumn{2}{c}{ Rerata kadar LDL $(\mathbf{m g} / \mathbf{d l})$} & \multirow{2}{*}{$\boldsymbol{\Delta}(\boldsymbol{\%})$} & \multirow{2}{*}{ ANOVA } \\
\cline { 2 - 3 } & Sebelum & Sesudah & & \multirow{2}{*}{ ANOV } \\
K & $27.24 \pm 5.559$ & $29.57 \pm 5.188$ & 8.55 & 0.200 & \\
P1 & $24.77 \pm 7.229$ & $26.11 \pm 6.980$ & 5.41 & 0.414 & \multirow{2}{*}{0.680} \\
P2 & $30.95 \pm 5.345$ & $31.24 \pm 2.517$ & 0.01 & 0.865 & \\
\hline
\end{tabular}

Berdasarkan Tabel 2, dapat diketahui bahwa LDL pada setiap kelompok mengalami peningkatan yang tidak bermakna $(p>0.05)$. Peningkatan tertinggi terdapat pada kelompok K (8.55\%), peningkatan kadar LDL pada kelompok P1 lebih kecil dibanding kelompok K yaitu sebesar $5.41 \%$, sementara pada kelompok P2 cenderung sama dengan kadar LDL sebelum intervensi. Peningkatan kadar LDL kelompok P2 hanya sebesar $0.01 \%$. Berdasarkan data di atas dapat dikatakan bahwa semakin besar dosis yoghurt koro pedang yang diberikan, peningkatan kadar LDL tikus setelah intervensi semakin kecil.

Tabel 3. Perbedaan rerata kadar kolesterol HDL sebelum dan setelah diberikan yoghurt koro pedang pada tiap kelompok perlakuan

\begin{tabular}{|c|c|c|c|c|c|}
\hline \multirow{2}{*}{ Kelompok } & \multicolumn{2}{|c|}{ Rerata kadar HDL (mg/dl) } & \multirow{2}{*}{$\Delta(\%)$} & \multirow{2}{*}{$p$} & \multirow{2}{*}{ ANOVA } \\
\hline & Sebelum & Sesudah & & & \\
\hline $\mathrm{K}$ & $13.28 \pm 3.592$ & $12.98 \pm 4.445$ & -2.26 & 0.881 & \\
\hline $\mathrm{P} 1$ & $10.55 \pm 1.320$ & $13.71 \pm 4.517$ & 29.95 & 0.113 & 0.307 \\
\hline P2 & $11.11 \pm 2.226$ & $14.74 \pm 4.285$ & 32.67 & 0.132 & \\
\hline
\end{tabular}

Kadar kolesterol HDL pada semua kelompok tidak mengalami perubahan yang bermakna $(p>0.05)$. Kelompok kontrol mengalami penurunan rerata kadar HDL sebesar 2.26\%. Sementara itu, kadar HDL kelompok perlakuan 1 dan 2 mengalami kenaikan kadar HDL sebesar $29.95 \%$ dan $32.67 \%$. Meskipun begitu, tidak ada perbedaan pengaruh intervensi yang bermakna pada tiap kelompok. Peningkatan kadar HDL ini berbanding lurus dengan dosis pemberian yoghurt koro pedang. Semakin banyak dosis yoghurt koro pedang yang diberikan, semakin besar pula kadar HDL serum tikus. 


\section{PEMBAHASAN}

Peningkatan kadar LDL dan HDL setelah pemberian pakan tinggi kolesterol

Kadar kolesterol LDL dan HDL mengalami peningkatan setelah diberikan pakan tinggi kolesterol berupa suspensi otak sapi sebanyak $2 \mathrm{ml}$ selama 14 hari. Peningkatan LDL dan HDL tersebut disebabkan oleh kolesterol dan asam lemak jenuh pada suspensi otak sapi. Kolesterol yang berasal dari otak sapi diserap oleh usus halus kemudian bergabung dengan biosintesis kolesterol di hati dalam bentuk ester kolesterol. Ester kolesterol bersama dengan trigliserida yang juga disintesis di hati dari asam lemak bebas akan membentuk Very Low Density Lipoprotein (VLDL) yang kemudian menjadi Intermediate Density Lipoprotein (IDL) dan LDL dalam tubuh. ${ }^{3}$

Kandungan asam lemak jenuh juga dapat meningkatkan kadar LDL dengan meningkatkan pembentukan LDL pada serum, menurunkan aktivitas reseptor LDL, dan menghambat pembersihan lipoprotein kaya triasilgliserol. ${ }^{11,12}$ Pengaruh kolesterol dan asam lemak jenuh pada otak sapi ternyata juga memberikan dampak peningkatan kadar kolesterol HDL. Sebuah penelitian terdahulu mengenai pemberian diet tinggi lemak dan kolesterol pada tikus menunjukkan terjadinya peningkatan ukuran partikel HDL, peningkatan sekresi apolipoprotein A-1 dari hepatosit, peningkatan laju pengangkutan apo A-1, dan penurunan laju katabolisme fraksi apo A-1. Peningkatan jumlah dan laju pengangkutan HDL mungkin merupakan mekanisme adaptasi terhadap banyaknya kolesterol dalam darah. ${ }^{12,13}$

Otak sapi mengandung 3\% kolesterol dan $2.3 \%$ asam lemak jenuh. Asam lemak jenuh utama pada otak sapi adalah asam stearat $1.26 \%$, asam palmitat $0.92 \%$, asam behenat $0.03 \%$, asam margarat $0.03 \%$, asam miristat $0.03 \%$, dan asam arakhidat $0.02 \% .^{14}$

Peningkatan kadar LDL dan HDL setelah pemberian yoghurt koro pedang

Peningkatan kadar kolesterol LDL terjadi pada semua kelompok dengan peningkatan terbesar terjadi pada kelompok kontrol, sementara peningkatan pada kelompok perlakuan lebih sedikit dari kontrol. Semakin besar dosis yoghurt koro pedang yang diberikan, semakin kecil peningkatan kadar kolesterol LDL tikus. Hasil ini menunjukkan bahwa yoghurt koro mampu mencegah kenaikan kadar LDL dibandingkan dengan kelompok yang hanya diberikan pakan standar. Pemberian yoghurt koro pedang juga mampu meningkatkan kadar kolesterol HDL pada kedua kelompok perlakuan.

Kemungkinan penyebab kenaikan kadar LDL dan HDL tikus setelah diberikan yoghurt koro pedang adalah karena adanya asam lemak jenuh pada koro pedang. Kandungan asam lemak jenuh koro pedang dalam $100 \mathrm{~g}$ tepung koro pedang yaitu asam palmitat sebanyak 15.9-21.8\%, asam stearat sebanyak $1.92-7.37 \%$, asam lignoserat $1.68 \%$, asam arakhidat $0.83 \%$, asam behenat $0.65 \%$, asam miristat $0.51 \%$, asam serotat $0.58 \%$, asam trikosanoat $0.16 \%$, asam laurat $0.12 \%$, dan asam henikosanoat $0.07 \% .^{6}$ Asam lemak jenuh meningkatkan pembentukan LDL pada serum, menurunkan aktivitas reseptor LDL, menghambat pembersihan lipoprotein kaya triasilgliserol, dan memperlambat proses pengangkutan balik kolesterol sehingga kadar LDL dalam darah menumpuk. ${ }^{11,12}$

Selain meningkatkan kadar LDL, asam lemak jenuh juga mampu meningkatkan kadar HDL dengan meningkatkan sekresi apo A-1 dari hepatosit, meningkatkan laju pengangkutan apo A1, meningkatkan ukuran partikel HDL, dan menurunkan laju katabolisme fraksi apo A-1. Peningkatan jumlah dan laju pengangkutan HDL tersebut mungkin merupakan mekanisme adaptasi terhadap banyaknya kolesterol dalam darah. ${ }^{12,13}$ Kandungan asam lemak utama yang meningkatkan kadar kolesterol HDL adalah asam laurat, stearat, miristat, dan palmitat serta asam lemak tak jenuh oleat. Pada penelitian terdahulu, asam miristat menaikkan kadar HDL sebanyak 9\%, lebih tinggi dibanding asam lemak lain. ${ }^{15}$

Faktor lain yang menyebabkan peningkatan kadar LDL setelah masa intervensi adalah stres. Stres pada subjek penelitian diakibatkan oleh penimbangan berat badan yang dilakukan setiap hari, pemberian suspensi otak sapi dan yoghurt koro pedang melalui sonde, proses pengambilan darah, serta peningkatan suhu udara selama penelitian yang ditandai dengan penurunan berat badan dan asupan makan terutama setelah pengambilan darah dan kenaikan suhu ruang. Selama stres, mamalia akan menambahkan energi ekstra dalam bentuk asam lemak dan glukosa ke dalah darah. Asam lemak lemak dan glukosa ini diperoleh dari pemecahan triasilgliserol dari jaringan adiposa oleh lipase yang distimulasi catecholamine. Proses ini diinduksi oleh kortisol. Peningkatan asam lemak dan cortisol mengakibatkan insulin menjadi tidak sensitif dan meningkatkan sintesis triasilgliserol dan apo-B di hati. Sekresi VLDL oleh hati juga akan meningkat, 
VLDL ini akan menjadi LDL yang mengangkut kolesterol dalam darah. Temuan lain menunjukkan bahwa stres mengakibatkan pembersihan lipid dalam darah menurun sehingga terjadi penumpukan LDL dalam darah. ${ }^{16}$

Ada kemungkinan juga bahwa peningkatan kadar kolesterol LDL setelah masa intervensi dipengaruhi oleh efek metabolisme pemberian suspensi otak sapi yang berkelanjutan hingga setelah masa intervensi. Tingginya asupan kolesterol dapat menurunkan laju pembersihan LDL dalam darah ${ }^{11}$, sehingga diduga kadar LDL setelah 21 hari masa intervensi masih tetap tinggi.

Kenaikan kadar kolesterol LDL pada kelompok perlakuan lebih rendah dibanding kelompok kontrol disebabkan oleh beberapa hal yaitu keberadaan asam amino, fenol, saponin, tanin, isoflavon, flavonoid, serat, PUFA, dan oligosakarida pada koro pedang. Koro pedang merupakan sumber asam amino esensial yang cukup baik kecuali asam amino sistin dan methionin. Salah satu asam amino yang mampu menurunkan LDL adalah glisin. Pengaruh proses pengolahan koro pedang menjadi yoghurt terhadap kandungan zat penurun kolesterol tidak diketahui karena dalam tidak dilakukan pengujian pada penelitian ini. Kandungan glisin pada koro pedang berdasarkan penelitian terdahulu adalah sebesar 0.9 - $4.3 \mathrm{mg} / 100 \mathrm{mg}$ protein. Kandungan senyawa fenol, isoflavon, flavonoid, tanin, dan saponin dan koro pedang berturut-turut adalah $245.5 \mathrm{mg} / 100 \mathrm{~g}$, $0.081 \mathrm{mg} / 100 \mathrm{~g}, 52.05-68.12 \mathrm{mg} / 100 \mathrm{~g}, 0.9$ $\mathrm{g} / 100 \mathrm{~g}, \quad 572 \mathrm{mg} / 100 \mathrm{~g} \cdot{ }^{6-8,17,18}$ Isoflavon yang terdapat pada biji koro pedang adalah daidzein, glisitein dan genistein. Isoflavon dan flavonoid mencegah kenaikan kadar LDL yang lebih besar dengan meningkatkan aktifitas reseptor kolesterol LDL di hati sehingga ekskresi kolesterol ke feses pun meningkat. ${ }^{7}$ Flavonoid juga mampu menghambat aktivitas kolesterol asiltransferase di hati dan berperan sebagai antioksidan terhadap oksidasi LDL. Beberapa penelitian terhadap manusia normal dan hiperkolesterolemia menunjukkan flavonoid beberapa produk tanaman mampu menurunkan kadar LDL. ${ }^{19}$ Saponin mampu mengikat kolesterol dalam lumen usus, menghambat penyerapan kolesterol tersebut, dan/atau berikatan dengan asam empedu sehingga meningkatkan ekskresi kolesterol melalui feses.

Koro juga mengandung serat total sebanyak $17.68 \mathrm{~g} / 100 \mathrm{~g}$ berat kering koro dan $4.67 \%$ diantaranya adalah serat larut. ${ }^{6}$ Serat mampu menurunkan kadar LDL dalam darah dengan beberapa mekanisme. Mekanisme pertama yaitu, serat mampu mengikat asam empedu sehingga tidak dapat diabsorbsi dan disirkulasikan kembali. Serat yang mengikat asam empedu kemudian masuk ke usus besar untuk digradasi dan diekskresikan. Kedua, serat mampu mengalihkan pool (timbunan) asam empedu dari asam kolat menjadi chenodeoxycholic acid. Chenodeoxycholic acid dapat menghambat HMG CoA reduktase yang merupakan enzim yang berperan dalam biosintesis kolesterol sehingga kadar kolesterol LDL darah berkurang. Ketiga, mikroorganisme pendegradasi serat dalam usus mampu menghasilkan propionat atau asam lemak rantai pendek lainnya yang dapat menghambat sintesis asam lemak dan/atau kolesterol sehingga kadar LDL dalam tubuh berkurang. ${ }^{3}$ Hal ini sesuai dengan hasil penelitian sebelumnya mengenai pemberian serat larut pada penderita dislipidemia dengan terapi penurun lipid. Serat larut mampu menurunkan kadar LDL secara signifikan. ${ }^{20}$

Kandungan PUFA koro pedang mempengaruhi rendahnya peningkatan kolesterol LDL pada kelompok perlakuan dibanding kelompok kontrol. PUFA menurunkan kolesterol LDL dengan cara mengurangi laju pembentukan LDL dan meningkatkan laju pembersihan LDL. ${ }^{13}$ Dalam 100 g koro pedang terdapat $36.8-47.4 \mathrm{~g}$ asam oleat, 11.6-18.0 g asam linoleat, $6.62-13.3 \mathrm{~g}$ asam linolenat, 2.02 - $9.44 \mathrm{~g}$ asam palmitoleat, $2.20 \mathrm{~g}$ asam eikosanoat dan asam lemak tak jenuh lainnya dalam jumlah kecil. ${ }^{6}$

Koro pedang mengandung prebiotik oligosakarida golongan rafinosa (rafinosa, stakiosa, verbaskosa) yang pada umumnya ditemukan pada biji-bijian. Oligosakarida golongan rafinosa tersebut juga mungkin berkontribusi terhadap penurunan kadar LDL dan peningkatan kadar HDL. Mekanisme penurunan kadar LDL oleh oligosakarida tersebut adalah dengan menurunkan penyerapan kolesterol disertai dengan peningkatan ekskresi melalui feses. Prebiotik yang bersifat tidak dapat dicerna juga dapat meningkatkan viskositas pada saluran pencernaan dan memicu katabolisme kolesterol pada hati sehingga kolesterol darah menurun. Penelitian terdahulu mengenai pemberian oligosakarida serupa, yaitu pada kedelai terhadap tikus Wistar hiperkolesterolemia menunjukkan perbaikan profil lipid yang signifikan. Kadar LDL tikus mengalami penurunan $43.0 \%$ dan HDL meningkat $81.9 \%{ }^{21}$

Proses fermentasi koro pedang dengan bakteri asam laktat membantu mencegah kenaikan kolesterol LDL dengan dihasilkannya enzim $\beta$ glukosidase dalam jumlah yang banyak. Enzim ini 
menghidrolisis isoflavon dan saponin menjadi aglikon. Aglikon merupakan senyawa bebas dari isoflavon dan saponin yang lebih tinggi aktivitasnya dalam mencegah kenaikan kolesterol LDL. ${ }^{22,23}$

\section{SIMPULAN}

Pemberian yoghurt koro pedang meningkatkan kadar kolesterol HDL namun tidak mampu menurunkan kadar kolesterol LDL serum tikus dislipidemia. Pemberian yoghurt koro pedang bahkan meningkatkan kadar LDL secara tidak bermakna meskipun peningkatan pada kelompok pemberian yoghurt dengan dosis $4.5 \mathrm{ml}$ lebih rendah dibanding kelompok dosis $2.1 \mathrm{ml}$ dan kelompok kontrol. Ada kemungkinan pemberian yoghurt koro pedang mampu menghambat peningkatan kadar kolesterol LDL. Kadar kolesterol HDL meningkat pada kelompok pemberian yoghurt dengan dosis $2.1 \mathrm{ml}$ dan peningkatan lebih besar lagi pada kelompok dengan dosis $4.5 \mathrm{ml}$. Semakin besar dosis yoghurt koro pedang yang diberikan, kenaikan kadar HDL semakin tinggi dan peningkatan kadar LDL semakin rendah.

\section{DAFTAR PUSTAKA}

1. World Health Organization. Fact sheets: Cardiovascular diseases (CVDs). [cited 2013

March 13]. Available from URL:

http://www.who.int/mediacentre/factsheets/fs317/e n/index.html

2. Departemen Kesehatan RI. Riset Kesehatan Dasar (Riskesdas) 2007. Jakarta: Depkes RI 2007.

3. Gropper SS, Smith JL, Groff JL. Advanced Nutrition and Human Metabolism. $5^{\text {th }}$ ed. Belmont: Wadsworth; 2009. p. 115;74.

4. Krummel DA. Medical Nutrition Therapy for Cardiovascular Disease. In: Mahan LK, EscottStump S, editors. Krause's Food Nutrition and Diet Therapy. $12^{\text {th }}$ ed. Pensylvania: Saunders; 2008. p.834;60.

5. Nimenibo-Uadia R. Effect of aquous extract of Canavalia ensiformis seeds on hyperlipidaemia and hyperketonaemia in alloxan-induced diabetic rats. Biokemistri 2003; 15:7 - 15 .

6. Sridhar KR and Seena S. Nutritional and antinutritional significance of four unconventional legumes of the genus Canavalia - A comparative study. Food Chemistry. 2005; 99: 267-288.

7. Istiani Y. Karakterisasi senyawa bioaktif isoflavon dan uji aktivitas antioksidan dari ekstrak etanol tempe berbahan baku koro pedang (Canavalia ensiformis) [thesis]. Surakarta: Universitas Sebelas Maret. 2010.
8. Doss A, Pugalenthi M, and Vadivel V. Antioxidant Activity Of Raw And Differentially Processed Under-Utilized Tropical Legume Canavalia ensiformis L. Dc Seeds, South India. IIOABJ Vol. 2. 2011; (8):27-32.

9. Sumarna. Hydrolysis of bioactive isoflavone in soymilk fermented with $\beta$-glucosidase producing lactic acid bacteria from local fermented foods of Indonesian. Malaysian Journal of Microbiology Vol 6. 2009; (1): 30-40

10. Belitz HD, Grosch W, Schieberle P. Food chemistry 3rd Edition. Springer: Berlin. 2004. p:765

11. Merchant AT, et al. Interrelation of saturated fat, trans fat, alcohol intake, and subclinical atherosclerosis. Am J Clin Nutr 2008; 87:168-174

12. Siri-Tarino PW, Sun Q, Hu FB, Krauss RM. Saturated Fatty Acids and Risk of Coronary Heart Disease: Modulation by Replacement Nutrients. Curr Atheroscler Rep. 2010; 12: 384 - 390

13. Hayek T, et al. Dietary Fat Increases High Density Lipoprotein (HDL) Levels Both by Increasing the Transport Rates and Decreasing the Fractional Catabolic Rates of HDL Cholesterol Ester and Apolipoprotein (Apo) A-I. J Clin Invest vol 91. 1993: 1665:1671

14. Condé Nast. Nutrition Facts: Beef, variety meats and by-products, brain, raw. [cited 2013 November 18]. Available from URL: http://nutritiondata.self.com/facts/beefproducts $/ 3461 / 2$

15. Zock PL, de Vries JH, Katan MB. Impact of myristic acid versus palmitic acid on serum lipid and lipoprotein levels in healthy women and men. Arterioscler Thromb Vasc Biol. 1994;14:567-575

16. Steptoe A and Brydon L. Associations Between Acute Lipid Stres Responses and Fasting Lipid Levels 3 Years Later. Health Phsychology Vol 4. 2005;6:601-607

17. Agbede JO and Aletor VA. Studies of the chemical composition and protein quality evaluation of differently processed Canavalia ensiformis and Mucuna pruriens seed flours. Journal of Food Composition and Analysis 18 (2005) 89-103.

18. Doss A, Pugalenthi $M$, and Vadivel V, Rajendrakumaran D. Phenols, Flavonoids and Antioxidant activity of underutilized legume seeds. Asian J. Exp. Biol. Sci. Vol 1 (3) 2010 : 700-705

19. Huffman F, Vaccaro J, Zarini G, Dixon Z. Dietary Intake Of Flavonoids And HDL- And LDLCholesterol In Two Black Ethnicities With And Without Type 2 Diabetes. The Internet Journal of Cardiovascular Research. 2010 Vol 7 No 2.

20. Ramos SC, et al. The role of soluble fiber intake in patients under highly effective lipid-lowering therapy. Nutrition Journal 2011, 10:80

21. Ooi LG and Liong MT. Cholesterol-Lowering Effects of Probiotics and Prebiotics: A Review of 
in Vivo and in Vitro Findings. Int. J. Mol. Sci. 2010; 11: 2499-2522

22. Sumarna. Hydrolysis of bioactive isoflavone in soymilk fermented with $\beta$-glucosidase producing lactic acid bacteria from local fermented foods of Indonesian. Malaysian Journal of Microbiology Vol 6. 2009; (1): 30-40

23. Belitz HD, Grosch W, Schieberle P. Food chemistry 3rd Edition. Springer: Berlin. 2004. p:765 